\title{
A comparative study of two
} methods to determine acrosome integrity of frozen-thawed boar sperm: FITC-PNA/EthD-1 versus Coomassie blue staining

\author{
J. Rungruangsak, J. Suwimonteerabutr, K. Buranaamnuay, \\ A. Chankrachang and P. Tummaruk*
}

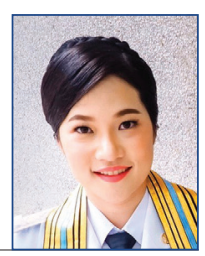

\section{Abstract \\ Coomassie blue staining has been reported as an effective and inexpensive method for evaluating the acrosome integrity of spermatozoa, though to date its use to evaluate cryopreserved boar sperm has not been reported. Moreover, there is no information concerning the agreement between Coomassie blue staining and fluorescein isothiocyanate conjugated peanut agglutinin and ethidium homodimer (FITC-PNA/EthD-1) methods for assessing sperm acrosome integrity for any species. The current study was performed to determine the efficacy and agreement between Coomassie blue and FITC-PNA/EthD-1 staining methods for evaluating the acrosome integrity of frozen-thawed boar sperm. A total of 25 semen samples were cryopreserved using lactose-egg yolk-based extender and}

loaded into 0.5 PVC-French straws. Sperm motility and motion characteristics were determined using a computer-assisted sperm analysis system. Sperm viability and plasma membrane integrity were evaluated using the SYBR-14/EthD-1 and hypo-osmotic swelling test, respectively. Acrosome integrity of frozen-thawed boar sperm was evaluated using both FITC-PNA/EthD-1 and Coomassie blue staining to assess the association between sperm acrosome integrity and agreement between these two methods. The average percent acrosome integrity of frozen-thawed boar sperm as determined by FITC-PNA/ EthD-1 and Coomassie blue staining was 48.8 $\pm 12.6 \%$ and $52.6 \pm 13.6 \%$, respectively $(P>0.05)$. Interestingly, Coomassie blue staining found a correlation between sperm viability and

\footnotetext{
Janyaporn RUNGRUANGSAK, Department of Obstetrics, Gynaecology and Reproduction, Faculty of Veterinary Science, Chulalongkorn University, Bangkok 10330, Thailand; Junpen SUWIMONTEERABUTR, Swine Reproduction Research Unit, Department of Obstetrics, Gynaecology and Reproduction, Faculty of Veterinary Science, Chulalongkorn University, Bangkok 10330, Thailand; Kakanang BURANAAMNUAY, Institute of Molecular Biosciences, Mahidol University 25/25 Phuttamonthon 4 Rd., Salaya, Nakhon Pathom 73170, Thailand; Arun CHANKRACHANG, Embryo Transfer Technology and Germplasm Research Center, Pakchong, Nakhonratchasima 30130, Thailand; Padet TUMMARUK*, DVM, MSc, PhD, (Corresponding author, e-mail: Padet.t@chula.ac.th), Swine Reproduction Research Unit, Department of Obstetrics, Gynaecology and Reproduction, Faculty of Veterinary Science, Chulalongkorn University, Bangkok 10330, Thailand
} 
acrosome integrity $(\mathrm{r}=0.609, P=0.002)$, while FITC-PNA/EthD-1 staining did not $(P>0.05)$. However, the acrosome integrity of frozenthawed boar sperm evaluated by FITC-PNA/ EthD-1 and Coomassie blue staining was significantly correlated $(\mathrm{r}=0.448, \quad P=0.025$, $n=25)$. The Bland-Altman plot determined that this agreement was acceptable. In conclusion, the acrosome integrity of the frozen-thawed boar sperm assessed via Coomassie blue staining was significantly correlated with that obtained via the FITC-PNA/EthD-1 staining method, and the two methods showed good agreement. Moreover, the significant association between the acrosome integrity of frozen-thawed boar sperm determined by Coomassie blue staining with other sperm quality parameters indicates that this is an effective method for assessing the acrosome integrity of frozen-thawed sperm in pigs.

Key words: acrosome integrity; boar; Coomassie blue; cryopreservation; FITC-PNA

\section{Introduction}

In general, viable and motile sperm obtained from ejaculated semen are not immediately ready for fertilization, as a period of physiological changes is required to develop fertilizing ability, which is known as 'capacitation' (Sirivaidyapong et al., 2000). The acrosomal status of spermatozoa needs to be safeguarded when sperm is preserved prior to artificial insemination, as acrosome-reacted sperm can no longer penetrate the zona pellucida. Therefore, to determine the efficacy of semen extender or any media used for sperm processing and storage, assessing the acrosomal status of sperm is of the utmost importance.

For the past 20 years, evaluation of the acrosome integrity of spermatozoa of many animal species has been based on the fluorescein isothiocyanate (FITC)conjugated peanut agglutinin (PNA) and ethidium homodimer-1 (EthD-1) staining method (FITC-PNA/EthD-1) (Fazeli et al., 1997; Sirivaidyapong et al., 2000; Laura et al., 2008; Ponglowhapan and Chatdarong, 2008; Chanapiwat et al., 2009; Chanapiwat et al., 2010; Pearodwong et al., 2019). This method is complicated and requires expensive equipment. Acrosome integrity of spermatozoa can also be detected using epifluorescence microscopy or flow cytometry (Kowalczyk et al., 2020). Despite giving accurate acrosome integrity results, these methods require even more complex equipment including fluorescence, therefore making them unsuitable for field assessments.

Coomassie blue staining has been reported to be an effective and inexpensive method for evaluating acrosome integrity of spermatozoa in several species (Pukazhenthi et al., 2006; Arakaki et al., 2019). Recently, a study in pigs demonstrated the use of Coomassie blue staining for evaluating acrosome integrity in liquid-preserved boar sperm (Chen et al., 2021). However, its use for evaluating acrosome integrity in cryopreserved boar sperm has never been demonstrated. Moreover, information on the agreement between Coomassie blue staining and FITC-PNA/EthD-1 for assessing sperm acrosome integrity is not available for any species. Therefore, the current study was performed to compare the efficacy and agreement between the Coomassie blue and FITC-PNA/EthD1 staining methods for evaluating the acrosome integrity of frozen-thawed boar sperm. The association between acrosome integrity of the frozen-thawed boar sperm as determined by the two methods and other sperm quality parameters was also investigated. 


\section{Materials and Methods}

The experiment was conducted in compliance with The Ethical Principles and Guidelines for the Use of Animals for Scientific Purposes by the National Research Council of Thailand (NRCT), and approved by the Institutional Animal Care and Use Committee (IACUC) in accordance with our university regulations (animal use protocol no. 1631032).

\section{Animals}

The experiment was conducted at the Swine Research and Development Centre, Nakhon Ratchasima, Thailand. A total of 25 semen samples were collected from 23 boars (9 Landrace, 7 Yorkshire, 5 Duroc and 2 Hybrid boars). The boars were proven sires used for semen collection. The ejaculates were selected based on their good semen quality, with $\geq 70 \%$ subjective motility and $\geq 75 \%$ normal morphology. All boars were housed in a conventional open-housing system and were allocated individual pens. The sperm-rich fraction of semen was collected using the gloved-hand technique. The interval between each semen collection was 5-7 days.

\section{Semen cryopreservation}

Semen was cryopreserved according to our previous protocol (Buranaamnuay et al., 2019). Briefly, the semen was diluted $(1: 1, \mathrm{v} / \mathrm{v})$ in extender, then cooled to $15^{\circ} \mathrm{C}$ and held for 2 hours. Following this, the semen was centrifuged at $15^{\circ} \mathrm{C}, 800 \times g$ for $10 \mathrm{~min}$. The sperm pellet was diluted in lactose-egg yolk (LEY) extender (80 $\mathrm{mL} \mathrm{11 \%} \mathrm{lactose} \mathrm{solution} \mathrm{and} 20 \mathrm{~mL}$ egg yolk) (extender II) to a concentration of $1.5 \times 10^{9}$ cells per $\mathrm{mL}$, then cooled to $4^{\circ} \mathrm{C}$ for 2 hours. The diluted sperm were then added to extender III (LEY extender, $10 \%$ glycerol and $1.5 \%$ Equex STM Paste; Nova Chemical Sales Inc., MA, USA) to a final concentration of $1 \times 10^{9}$ sperm per $\mathrm{mL}$ and loaded into 0.5 PVC-French straws (IMV, IMV Technologies, France). To freeze the samples, the straws were placed approximately $4 \mathrm{~cm}$ above liquid nitrogen for $20 \mathrm{~min}$, and then dropped into the liquid nitrogen. For thawing, straws were plunged into $50^{\circ} \mathrm{C}$ water for $12 \mathrm{sec}$.

\section{Sperm motility}

Sperm motility and motion characteristics were determined using the computer assisted sperm analysis (CASA) system (SCA ${ }^{\circledR}$ CASA System, MICROPTIC S.L., Barcelona, Spain). Images were taken under a phase contrast microscope with a green filter at 100x magnification. The frozen-thawed semen was diluted with phosphate buffer saline solution (PBS) at a ratio of 1:20. The diluted semen $(8 \mu \mathrm{L})$ was dropped onto a warmed slide $\left(37^{\circ} \mathrm{C}\right)$ and covered with a coverslip. A total of 1500 sperm cells from five different fields of each sample were randomly selected to determine sperm motility and motion characteristics. The motion characteristics of spermatozoa, including straight-line velocity (VSL, $\mu \mathrm{m} / \mathrm{sec}$ ), curvilinear velocity (VCL, $\mu \mathrm{m} /$ $\mathrm{sec}$ ), average path velocity (VAP, $\mu \mathrm{m} /$ $\mathrm{sec})$, linearity (LIN, \%), straightness (STR, $\%)$, wobble coefficient (WOB, \%), mean lateral head displacement (ALH, $\mu \mathrm{m})$ and beat cross frequency $(\mathrm{BCF}, \mathrm{Hz})$, were recorded using the CASA software.

\section{Sperm viability}

Sperm viability was evaluated with SYBR-14/EthD-1 (Fertilight ${ }^{\circledR}$, Sperm Viability Kit, Molecular Probes Europe, Leiden, Netherlands). Thawed semen $(10 \mu \mathrm{L})$ was diluted with PBS $(140 \mu \mathrm{L})$. Then, $50 \mu \mathrm{L}$ diluted semen was gently mixed with fluorescence solution, composed of SYBR-14 (2.7 $\mu \mathrm{L})$ and EthD1 (10 $\mu \mathrm{L})$. The mixed semen sample was incubated at $37^{\circ} \mathrm{C}$ for $20 \mathrm{~min}$. Two hundred stained sperm were evaluated under a fluorescence microscope at 1000x 
magnification with an oil objective lens. Under the fluorescence microscope, sperm heads with green luminescence were defined as having intact plasma membranes (live), while red luminescence was defined as damaged membranes (dead). Sperm viability was presented as the percentage of live sperm.

\section{Sperm plasma membrane integrity}

Sperm plasma membrane integrity was determined using the hypoosmotic swelling test (sHOST). The hypoosmotic solution was prepared with fructose and $\mathrm{Na}$-citrate in distilled water until final osmolality of $75.0 \mathrm{mOsm} / \mathrm{kg}$. Solution osmolality was measured by freezing point depression. Each frozen-thawed semen sample $(100 \mu \mathrm{L})$ was mixed with $1000 \mu \mathrm{L}$ hypoosmotic solution and incubated at $38^{\circ} \mathrm{C}$ for $30 \mathrm{~min}$. Sperm were then fixed with $1000 \mu \mathrm{L}$ hypoosmotic solution with 5\% formaldehyde (Merck, Darmstadt, Germany). A well-mixed sample $(10 \mu \mathrm{L})$ was placed on a glass slide with a coverslip. A total of 200 sperm were evaluated under a light microscope at 400x magnification. Coiled tail sperm were defined as sperm with functional sperm membranes. The proportion of sperm with functional sperm membranes was presented as a percentage.

\section{Sperm acrosome integrity}

\section{FITC-PNA/EthD-1}

The acrosome integrity of frozenthawed boar sperm was evaluated using FITC-PNA/EthD-1 staining. FITCPNA/EthD-1 was performed according to a previously described protocol (Chanapiwat et al., 2012) with some modifications. Briefly, $10 \mu \mathrm{L}$ diluted semen was mixed with $10 \mu \mathrm{L}$ EthD1 and incubated at $37^{\circ} \mathrm{C}$ for $15 \mathrm{~min}$. Thereafter, $5 \mu \mathrm{L}$ mixture was smeared on a slide and fixed with $95 \%$ ethanol for $30 \mathrm{sec}$. Each sample was smeared with $15 \mu \mathrm{L}$ FITC-PNA (FITC-PNA: PBS $=1: 10, \mathrm{v}: \mathrm{v})$. The sample was incubated in a moist chamber at $4^{\circ} \mathrm{C}$ for $30 \mathrm{~min}$, then rinsed with PBS and dried. For the assessment, 200 sperm were viewed under a fluorescence microscope at 1000x magnification, and the sperm acrosome was classified as intact or reacted (Figure $1)$. The proportion of intact acrosomes was presented as a percentage.

\section{Coomassie blue staining}

Coomassie blue staining was performed according to a previous report (Larson and Miller, 1999) with some modifications. Briefly, sperm were fixed with $4 \%$ paraformaldehyde solution (110 mM Na $\mathrm{HPO}_{4^{\prime}} 2.5 \mathrm{mM} \mathrm{NaH} \mathrm{PO}_{4}$, $4 \%$ paraformaldehyde $\mathrm{pH} 7.4$ ) for 10 min. Sperm were centrifuged at $450 \mathrm{x}$ $g$ for 5 min twice using $500 \mu \mathrm{L} 100 \mathrm{mM}$ ammonium acetate $(\mathrm{pH} 9.0)$. The final sperm pellet was re-suspended in $1 \mathrm{~mL}$ $100 \mathrm{mM}$ ammonium acetate, and $50 \mu \mathrm{L}$ sperm suspension was smeared on glass microscope slides and air dried, then incubated in freshly prepared Coomassie blue stain (0.22\% Coomassie Blue G-250, $50 \%$ methanol, $10 \%$ glacial acetic acid, $40 \%$ water) for $2 \mathrm{~min}$. Slides were washed with distilled water to remove excess stain and air-dried, and then covered with coverslips. For the assessment, a total of 200 sperm were viewed (1000x) using bright field microscopy. The spermatozoa with an intact acrosome stained purple-blue and the posterior part of the acrosome was either not stained or stained a light purple (Figure 1 ). The proportion of intact acrosomes was presented as a percentage.

\section{Statistical analysis}

Statistical analysis was carried out using SAS version 9.4 (SAS Inst. Inc., Cary, NC, USA). Descriptive statistics on the sperm characteristics post-thawing were calculated using the MEANS procedure of SAS (PROC MEANS). The difference in acrosome integrity of the frozen-thawed boar sperm obtained 
via FITC-PNA/EthD-1 and Coomassie blue staining was compared using a paired $t$-test. Pearson's correlation was performed to determine the association between acrosome integrity determined by FITC-PNA/EthD-1 and Coomassie blue staining. Agreement between the two methods of measurement was assessed using a Bland-Altman plot (Bland and Altman 1986). For all analyses, differences of $P<0.05$ were regarded as statistically significant.

\section{Results}

Descriptive statistics of the sperm quality parameters of the frozen-thawed boar semen are presented in Table 1 . The average acrosome integrity of the frozenthawed boar sperm determined by FITC-PNA/EthD-1 and Coomassie blue staining was $48.0 \pm 12.1$ and $52.8 \pm 12.9 \%$, respectively $(P>0.05)$. Although the percentage of acrosome integrity assessed by FITC-PNA/EthD-1 was $4.8 \%$ lower than that assessed by Coomassie blue staining, the difference was not statistically significance $(P=0.093)$. The correlations between sperm quality parameters and acrosome integrity of frozen-thawed boar sperm determined using the FITCPNA/EthD-1 and Coomassie blue staining method are presented in Table 2. Interestingly, most sperm quality

Table 1. Descriptive statistics of sperm quality parameters of frozen-thawed boar semen $(n=25)$

\begin{tabular}{|l|c|c|}
\hline Variable (\%) & mean \pm SD & range \\
\hline Fresh semen & & \\
\hline Sperm motility (\%) & $71.4 \pm 4.5$ & $70.0-90.0$ \\
\hline Sperm concentration (x $\left.10^{6} \mathrm{sperm} / \mathrm{mL}\right)$ & $817 \pm 224$ & $448-1287$ \\
\hline Frozen-thawed semen & & \\
\hline Sperm motility (\%) & $41.9 \pm 17.2$ & $12.5-69.9$ \\
\hline Progressive motility (\%) & $18.8 \pm 11.1$ & $2.0-39.2$ \\
\hline Sperm viability (\%) & $46.0 \pm 11.8$ & $23.0-70.0$ \\
\hline Plasma membrane integrity (\%) & $37.6 \pm 12.8$ & $15.0-62.5$ \\
\hline Acrosome integrity & & \\
\hline FITC-PNA/EthD-1 & $48.0 \pm 12.1$ & $26.0-74.0$ \\
\hline Coomassie blue & $52.8 \pm 13.9$ & $25.0-74.0$ \\
\hline Sperm motion characteristics & & \\
\hline VCL & $37.6 \pm 8.1$ & $21.7-49.1$ \\
\hline VSL & $13.7 \pm 5.0$ & $5.5-21.2$ \\
\hline VAP & $23.1 \pm 7.5$ & $10.1-35.8$ \\
\hline LIN & $30.0 \pm 6.6$ & $16.0-39.5$ \\
\hline STR & $49.3 \pm 5.3$ & $35.9-57.7$ \\
\hline WOB & $54.1 \pm 8.5$ & $36.8-68.2$ \\
\hline ALH & $1.9 \pm 0.3$ & $1.3-2.2$ \\
\hline BCF & $3.3 \pm 1.0$ & $1.4-4.9$ \\
\hline VCL & & \\
\hline
\end{tabular}

VCL $(\mu \mathrm{m} / \mathrm{s})$ : velocity curved line, VSL $(\mu \mathrm{m} / \mathrm{s})$ : velocity straight line, VAP $(\mu \mathrm{m} / \mathrm{s})$ : velocity average path, LIN $(\%)$ : linearity (VSL divided by VCL), STR (\%): straightness (VSL divided by VAP), WOB ( $\mu \mathrm{m} / \mathrm{s})$ : wobble ALH $(\mu \mathrm{m})$ : Amplitude of lateral head displacement BCF $(\mathrm{Hz})$ : beat-cross frequency 
Table 2. Pearson's correlation coefficient ( $r$ ) between sperm quality parameters and acrosome integrity of frozen-thawed boar sperm determined using the FITC-PNA/EthD-1 and Coomassie blue staining methods

\begin{tabular}{|l|c|c|}
\multirow{2}{*}{ Sperm quality parameters } & \multicolumn{2}{|c|}{ Acrosome integrity (\%) } \\
\cline { 2 - 3 } & FITC-PNA/EthD-1 & Coomassie blue \\
\hline Sperm motility (\%) & NS & NS \\
\hline Progressive motility (\%) & NS & $0.478^{*}$ \\
\hline Sperm viability (\%) & NS & $0.609^{* *}$ \\
\hline Plasma membrane integrity (\%) & NS & NS \\
\hline Sperm motion characteristics & & \\
\hline VCL & NS & $0.502^{* *}$ \\
\hline VSL & NS & $0.551^{* *}$ \\
\hline VAP & NS & $0.538^{* *}$ \\
\hline LIN & NS & $0.487^{* *}$ \\
\hline STR & NS & $0.447^{*}$ \\
\hline WOB & NS & $0.509^{* *}$ \\
\hline ALH & NS & NS \\
\hline BCF & NS & $0.517^{* *}$ \\
\hline
\end{tabular}

Significant levels were indicated as ${ }^{*} P<0.05,{ }^{* *} 0.05<P<0.01,{ }^{* * *} P<0.001$ and NS $=P>0.05$; VCL $(\mu \mathrm{m} / \mathrm{s})$ : velocity curved line, VSL $(\mu \mathrm{m} / \mathrm{s})$ : velocity straight line, VAP $(\mu \mathrm{m} / \mathrm{s})$ : velocity average path, LIN $(\%)$ : linearity (VSL divided by VCL), STR $(\%)$ : straightness (VSL divided by VAP), WOB $(\mu \mathrm{m} / \mathrm{s})$ : wobble ALH $(\mu \mathrm{m})$ : Amplitude of lateral head displacement $\mathrm{BCF}(\mathrm{Hz})$ : beat-cross frequency

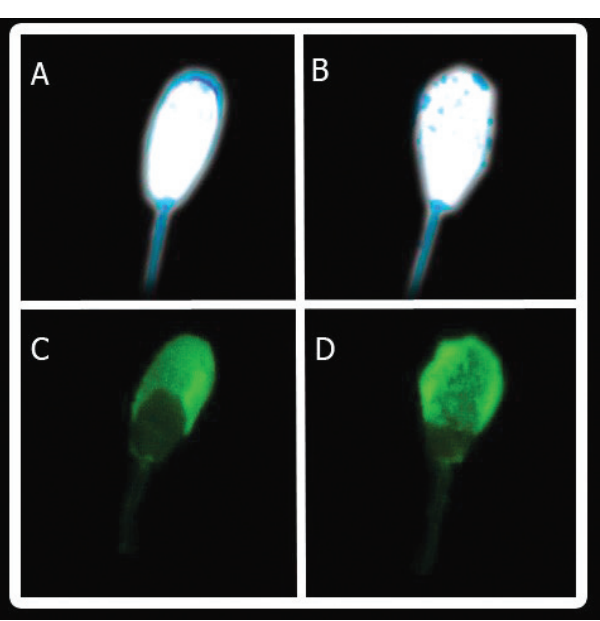

Figure 1. (A and B) Frozen-thawed boar spermatozoa with Coomassie blue staining demonstrating spermatozoa with intact acrosome (A) and reacted acrosome (B). (C and D) Frozenthawed boar spermatozoa with fluorescein isothiocyanate conjugated peanut agglutinin and ethidium homodimer-1 (FITC-PNA/EthD-1) staining demonstrating spermatozoa with intact acrosome (C) and reacted acrosome (D) parameters were significantly correlated with the acrosome integrity of frozenthawed boar sperm as determined using the Coomassie blue staining method, but not the FITC-PNA/EthD-1 staining method. For instance, sperm viability as determined using SYBR-14/EthD-1 was correlated with the Coomassie blue acrosome integrity ( $\mathrm{r}=0.609, P=0.002)$, but not with FITC-PNA/EthD-1 staining acrosome integrity $(P>0.05)$. However, the acrosome integrity of frozen-thawed boar sperm evaluated by FITC-PNA/ EthD-1 and Coomassie blue staining was significantly correlated ( $\mathrm{r}=0.448, P=0.025$, $n=25$ ) (Figure 2). This agreement was determined to be acceptable based on the Bland-Altman plot (Figure 3).

\section{Discussion}

In the present study, acrosome integrity of frozen-thawed boar 


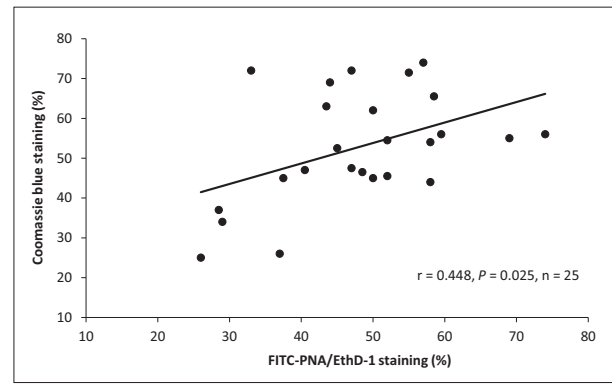

Figure 2. Pearson's correlation between acrosome integrity of frozen-thawed boar sperm determined by Coomassie blue and FITC-PNA/ EthD-1 staining

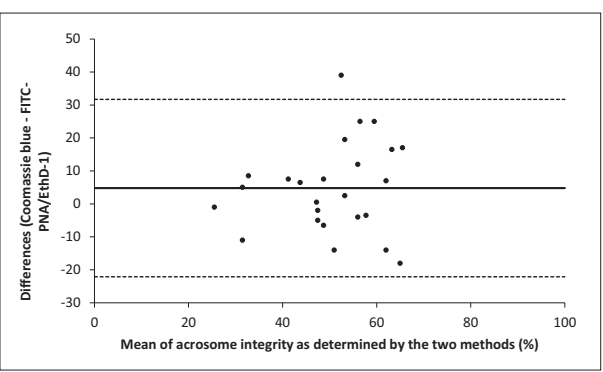

Figure 3. Bland-Altman plot illustrating agreement between Coomassie blue staining and FITC-PNA/EthD-1 for evaluating acrosome integrity of frozen-thawed boar semen

spermatozoa determined by FITC-PNA/ EthD-1 averaged $48.8 \%$ and ranged between 26.0 and $74.0 \%$. This data is consistent with previous studies (Chanapiwat et al., 2009; Pearodwong et al., 2019). Chanapiwat et al. (2009) demonstrated that the average acrosome integrity of extended fresh boar sperm was $83.7 \%$, while the average acrosome integrity of frozen-thawed boar sperm was $31.9-49.1 \%$. This indicates that the cryopreservation process used in the current study dramatically reduced the percentage of sperm with an intact acrosome. Nevertheless, the percentage of intact acrosomes in some ejaculates remained high (up to $74 \%$ ), indicating that the freezability of boar sperm as indicated by acrosome defects is highly variable. Therefore, assessing the acrosome integrity of frozen-thawed boar sperm is essential to confirm the fertilizing ability of this semen.

Recently, Chen et al. (2021) used Coomassie blue to determine the acrosome integrity of extended fresh boar semen kept at $17^{\circ} \mathrm{C}$ for 3 days. They demonstrated that the proportion of sperm with an intact acrosome in semen extender with a low concentration of glucose $(30.6 \mathrm{mM})$ was significantly higher than in semen extender containing a high concentration of glucose (153.0 $\mathrm{mM}$ ) after incubation at $17^{\circ} \mathrm{C}$ for 3 days $(92.5 \%$ versus $89.4 \%)$. As indicated in previous studies (Chanapiwat et al., 2009; Chen et al., 2021), the acrosome integrity of extended fresh semen is relatively high and is still used as an important fertilizing capacity parameter for boar semen preservation. In the current study, the acrosome integrity of frozen-thawed boar sperm determined by Coomassie blue staining was significantly associated with most sperm quality parameters, e.g., sperm viability and sperm motion characteristics post-thawing. On the other hand, the acrosome integrity of frozen-thawed boar sperm determined by the FITC-PNA/EthD-1 method was not significantly correlated with other sperm quality parameters. This could be explained by the relatively low number of observations used in the present study (i.e., $n=26$ samples) and the high variation in the results obtained with the FITCPNA/EthD-1 method. Nevertheless, the significant association between acrosome integrity of frozen-thawed boar sperm determined by Coomassie blue staining and other sperm quality parameters indicates that Coomassie blue staining is an effective method for assessing the acrosome integrity of frozen-thawed boar sperm.

In dog sperm, acrosomal status can be visualized using FITC-PNA, with binding limited to the outer acrosomal membrane and no staining on any other 
part of the sperm membrane, as the outer acrosomal membrane is the specific binding site for PNA (Sirivaidyapong et al., 2000). In boar spermatozoa, during the acrosomal reaction process, the sperm plasma membrane fuses with the outer acrosomal membrane and results in the release of the acrosomal contents. This process enables detection of the acrosome reaction using PNA and fluorescence microscopy (Fazeli et al., 1997). For this reason, FITC-PNA is commonly used as a reliable probe for detection of the acrosome reaction in boar spermatozoa. This technique allows for distinctions between stages of the acrosome reaction, i.e., intact, reacting and reacted acrosome (Fazeli et al., 1997). Larson and Miller (1997) demonstrated that acrosomal status can also be determined quickly using the Coomassie blue G-250 staining procedure. Acrosome-intact sperm stained darkly near the apical portion of the sperm head (Figure 1A) in the sperm acrosome, while acrosome-reacted sperm exhibited very faint or no staining in the acrosome region (Figure 1B). The difference between spermatozoa with intact and reacted acrosomes is clear and the percentage of intact or reacted acrosomes can be confirmed by bright field microscopy (Larson and Miller, 1997). These studies confirm the feasibility of determining acrosome integrity of boar sperm using either the FITC-PNA or Coomassie blue staining procedure. Both procedures are useful for male fertility evaluations. In the present study, both techniques were applied to determine the percentage of frozen-thawed boar sperm with an intact or reacted acrosome. The agreement between the acrosome integrity results obtained from each technique was acceptable.

In conclusion, the acrosome integrity of the frozen-thawed boar sperm assessed with Coomassie blue staining was significantly correlated with that obtained via the FITC-PNA/EthD-1 staining method, and the acrosome integrity obtained using these two methods showed good agreement. Moreover, the significant association between acrosome integrity of frozen-thawed boar sperm determined by Coomassie blue staining and other sperm quality parameters indicates that Coomassie blue staining is an effective method for assessing the acrosome integrity of frozen-thawed sperm in boars.

\section{Acknowledgement}

Financial support for this study was provided by the $90^{\text {th }}$ Anniversary of Chulalongkorn University Fund (Grant number GCUGR1125604078M). P. Tummaruk was awarded a Thailand Science Research and Innovation Senior Researcher Scholar grant (RTA6280013). J Rungruangsak is a grantee of the Research and Researcher for Industry RRI Master of Science Degree Programme, TSRI (MSD59I0067). Chulalongkorn University supported the One Health Research Cluster. The authors are grateful to the embryo transfer technology and germplasm research centre and their staff for help with boar semen processing. All boar semen samples were provided by the Swine Research and Development Centre, Department of Livestock Development, Nakhon Ratchasima, Thailand.

\section{References}

1. ARAKAKI, P. R., P. A. B. SALGADO, J. D. D. A. LOSANO, M. H. BLANK, M. NICHI and R. J. G. PEREIRA (2019): Assessment of different sperm functional tests in golden-headed lion tamarins (Leontopithecus chrysomelas). Am. J. Primatol. 81, e23034.

2. BLAND, J. M. and D. G. ALTMAN (1986): Statistical methods for assessing agreement between two methods of clinical measurement. Lancet 1(8476), 307-310.

3. BURANAAMNUAY, K., P. TUMMARUK, J. SINGLOR, H. RODRIGUEZ-MARTINEZ and M. TECHAKUMPHU (2009): Effects of straw volume and Equex-STM ${ }^{\circledR}$ on boar sperm quality after cryopreservation. Reprod. Domest. Anim. 44, 69-73.

4. CHANAPIWAT, P., K. KAEOKET and P. TUMMARUK (2009): Effects of DNA-enriched hen egg yolk and L-cysteine supplementation on quality of cryopreserved boar semen. Asian J. Androl. 11, 600-608.

5. CHANAPIWAT, P., K. KAEOKET and P. TUMMARUK (2010): The sperm DNA damage after cryopreservation of boar semen in relation to postthawed semen qualities, antioxidant supplementation and boars effect. Thai J. Vet. Med. 40, 187-193. 
6. CHANAPIWAT, P., K. KAEOKET and P. TUMMARUK (2012): Improvement of the frozen boar semen quality by docosahexaenoic acid (DHA) and L-cysteine supplementation. African J. Biotech. 11, 3697-3703.

7. CHEN, G., L. REN, Z. CHANG, Y. ZHAO, Y. ZHANG, D. XIA, R. ZHAO and B. HE (2021): Lysine acetylation participates in boar spermatozoa motility and acrosome status regulation under different glucose conditions. Theriogenology 159, 140-146.

8. FAZELI, A. R., W. J. HAGE, F. P. CHENG, W. VOORHOUT, A. MARKS, M. M. BEVERS and B. COLENBRANDER (1997): Acrosome-intact boar spermatozoa initiate binding to the homologous zona pellucida in vitro. Biol. Reprod. 56, 430-438.

9. KOWALCZYK, A., E. LUKASZEWICZ, T. STRZALA, A. PARTYKA and J. ROSENBERGER (2020): Characteristics of capercaillie (Tetrao urogallus) semen analyzed with flow cytometry combined with fertility results. Reprod. Domest. Anim. 55, 984-991.

10. LARSON, J. L. and D. J. MILLER (1999): Simple histological stain for acrosomes on sperm from several species. Mol. Reprod. Dev. 52, 445-449.
11. LAURA, S., V. MARCIANÓ and A. CARPINO (2008): Prostasome-like vesicles stimulate acrosome reaction of pig spermatozoa. Reprod. Biol. Endocrinol. 6, 5.

12. PEARODWONG, P., J. SUWIMONTEERABUTR, J. RUNGRUANGSAK and P. TUMMARUK (2019): Comparison of egg yolk-based and soybean lecithin-based extenders for cryopreservation of boar semen. Vet. stn. 50, 531-540.

13. PONGLOWHAPAN, S. and K. CHATDARONG (2008): Effects of Equex STM Paste on the quality of frozen-thawed epididymal dog spermatozoa. Theriogenology 69, 666-672.

14. PUKAZHENTHI, B., D. LAROE, A. CROSIER, L. M. BUSH, R. SPINDLER, K. M. PELICAN, M. BUSH, J. G. HOWARD and D. E. WILDT (2006): Challenges in cryopreservation of clouded leopard (Neofelis nebulosi) spermatozoa. Theriogenology 66, 1790-1796.

15. SIRIVAIDYAPONG, S., F. P. CHENG, A. MARKS, W. F. VOORHOUT, M. M. BEVERS and B. COLENBRANDER (2000): Effect of sperm diluent on the acrosome reaction in canine sperm. Theriogenology 53, 789-802.

\section{Komparativna studija dviju različitih metoda određivanja integriteta akrosome smrznute pa odmrznute sperme nerasta: bojanje s FITC-PNA/EthD-1 u usporedbi s bojanjem Coomassie plavom}

Janyaporn RUNGRUANGSAK, Department of Obstetrics, Gynaecology and Reproduction, Faculty of Veterinary Science, Chulalongkorn University, Bangkok 10330, Thailand; Junpen SUWIMONTEERABUTR, Swine Reproduction Research Unit, Department of Obstetrics, Gynaecology and Reproduction, Faculty of Veterinary Science, Chulalongkorn University, Bangkok 10330, Thailand; Kakanang BURANAAMNUAY, Institute of Molecular Biosciences, Mahidol University 25/25 Phuttamonthon 4 Rd., Salaya, Nakhon Pathom 73170, Thailand; Arun CHANKRACHANG, Embryo Transfer Technology and Germplasm Research Center, Pakchong, Nakhonratchasima 30130, Thailand; Padet TUMMARUK*, DVM., MSc, PhD, Swine Reproduction Research Unit, Department of Obstetrics, Gynaecology and Reproduction, Faculty of Veterinary Science, Chulalongkorn University, Bangkok 10330, Thailand

Postoje izvješća da je bojanje Coomassie plavom učinkovita i jeftina metoda procjene integriteta akrosome spermija. Međutim, ne postoje izvješća o bojanju Coomassie plavom za procjenu integriteta akrosome krioprezervirane sperme nerasta. Nadalje, informacije u svezi podudarnosti između bojanja Coomassie plavom i fluorescein izotiocijanatom konjugiranim s aglutininom kikirikija i etidij homodimerom (FITC-PNA/ EthD-1) za procjenu integriteta akrosome spermija nisu dostupne niti za jednu vrstu. Stoga je ova studija provedena za određivanje učinkovitosti i podudarnosti između metoda bojanja Coomassie plavom i bojanja FITC-PNA/EthD-1 za procjenu integriteta akrosome smrznute pa odmrznute sperme nerasta. U eksperiment je uključeno ukupno 25 uzoraka sjemena. Sjeme je krioprezervirano uporabom razrjeđivača na bazi laktoze i žumanjka i pohranjeno u 0,5 PVC-pajete. Svojstva pokretljivosti i gibanja spermija ustvrđena su uporabom sustava za računalno potpomognutu analizu 
spermija. Vijabilnost spermija i integritet njihove stanične membrane procijenjeni su uporabom SYBR-14/EthD-1, odnosno hipoosmotskim testom bubrenja. Integritet akrosome smrtznute pa odmrznute sperme nerasta procijenjen je uporabom bojanja FITC-PNA/EthD-1 i Coomassie plavom. Procijenjena je povezanost između integriteta akrosome sperme ustvrđene pomoću bojanja FITC-PNA/EthD-1 i Coomassie plavom te podudarnost između dviju metoda mjerenja. Prosječni postotak integriteta akrosome smrznute pa odmrznute sperme nerasta ustvrđene bojanjem FITC-PNA/EthD-1 i Coomassie plavom bio je 48,8 $\pm 12,6 \%$, odnosno 52,6 $\pm 13,6 \%(P>0,05)$. Zanimljivo, vijabilnost spermija korelirala je s integritetom akrosome procijenjenom uporabom Coomassie plavom $(\mathrm{r}=0,609, P=0,002)$, ali nije korelirala kada je procjenjivana uporabom FITC-PNA/EthD-1 bojanja $(P>0,05)$. Međutim, integritet akrosome smrznute pa odmrznute sperme nerasta procijenjen bojanjem FITC-PNA/EthD-1 i Coomassie plavom značajno je korelirao $(\mathrm{r}=0,448$, $P=0,025, n=25)$. Uz to, podudarnost između bojanja Coomassie plavom i FITC-PNA za procjenu integriteta akrosome smrznute pa odmrznute sperme nerasta ustvrđena BlandAltmanovim grafikonom bila je prihvatljiva. Zaključno, integritet akrosome smrznute pa odmrznute sperme nerasta procijenjena bojanjem Coomassie plavom značajno je korelirao s onim dobivenim FITC-PNA/EthD1 metodom bojanja te su te dvije metode pokazale dobru podudarnost. Uz to, značajna povezanost između integriteta akrosoma smrznute pa odmrznute sperme nerasta koja je ustvrđena bojanjem Coomassie plavom i drugih parametara kakvoće sperme ukazuju na to da je bojanje Coomassie plavom učinkovita metoda procjene integriteta akrosome smrznute pa odmrznute sperme $u$ svinja.

Ključne riječi: integritet akrosome, nerast, Coomassie plava, krioprezervacija, FITC-PNA 